\title{
Speed Control of High Power Multiple Drive Belt Conveyors
}

\author{
Milan Vasićc ${ }^{1 *}$, Nenad Miloradović ${ }^{1}$, Mirko Blagojević ${ }^{1}$ \\ ${ }^{1}$ University of Kragujevac, Faculty of Engineering, Kragujevac (Serbia)
}

Belt conveyors play a very important role in the continuous transport of bulk and piece material, especially in the mining industry. However, the use of belt conveyors results in high electricity consumption. A reduction in the power consumption can be achieved by adjusting the speed of the belt conveyor to match the material flow. However, inappropriate and frequent speed changes can cause serious damage to the conveyor elements. This paper presents a procedure for adjusting the belt conveyor speed to match the profile of the material on the belt, as well as a detailed procedure for determining the time needed to accelerate/decelerate the belt conveyor. The research was performed on an actual $640 \mathrm{~m}$ long belt conveyor used for transport of overburden at the surface mine Drmno (Serbia). The simulation results show that the speed regulation is completely justified because the conveyor operated at speeds lower than nominal throughout the testing.

Keywords: Belt conveyors, Speed regulation, Dynamic behaviour

\section{INTRODUCTION}

Belt conveyors have a very important role in the continuous transport of bulk and piece material due to their extremely good performances (large capacity, high transport speed, large transport distance, simple construction, low maintenance costs, the ability to adapt to the terrain, reliability...). That is why they have a wide application in mining, both in underground and surface excavations.

In recent years, an increasing number of conveyors have been equipped with variable speed drives based on frequency converters using standard squirrel cage motors and gearboxes.

According to the standard DIN 22101 [1], the capacity of a conveyor is calculated on the basis of $80 \%$ the belt cross section utilisation. Kolonja et al. [2] point out that by using frequency regulation and increasing the speed during short intervals it is possible to have a fully loaded belt, even up to $117 \%$.

Among other things, due to the digging technology [3-5], excavators very rarely work at full capacity, i.e. the amount of material on the belt is smaller than nominal and there are some periods of idle time.

All this led to the conclusion that the material should be transported at speeds lower than nominal when the amount of material on the belt is smaller than nominal. This is made possible by frequency regulation of the drive motors.

A wide range of the electric motor speed and torque control enalbes a smooth start so that the changes in the belt tensile force are much smaller than with conventional drives with hydrodynamic coupling or slip rings. This directly reduces wear of all belt conveyor parts and reduces maintenance costs. In addition, compared to standard motors with constant voltage and frequency, these drives enable smooth electric braking to the minimum number of revolutions as well as a significant reduction in power consumption - between 7 and $24 \%$ according to [2].

However, it should be emphasized that this procedure is still in the development phase and that there are numerous limitations such as the requirements regarding the automatic adjustment of unloading hoppers at transfer points, which is ty pical for multi-conveyor systems.

Consequently, over the last few decades, an intensive research has been conducted in the field of defining energy models and algorithms for improving control [6-10].

According to Ristic [8], the speed change range is limited because there is no justification to reduce the speed of the belt conveyor below the speed corresponding to the nominal power of $50 \%$. The maximum speed is set to 100 $125 \%$, depending on the capacity of the excavator and the operating conditions.

Furthermore, researchers have been engaged in the dynamic analysis of transient processes that occur when starting and stopping the conveyor [11-13].

In the recent years, there has been a very intensive research into the risks during transition operations, while accelerating and decelerating. Improper and frequent speed changes can cause serious damage to the belt conveyor elements if there are no appropriate restrictions. He, Pang and Lodewijks [14-16] note that in temporary acceleration or deceleration operations there are risks of belt slipping, material spilling away from the belt, belt breaking at the splicing area, motor over-heating and pushing the motor into regenerative operation.

Based on a review of the literature, it can be concluded that researchers worldwide are dealing with various aspects of belt conveyors in order to increase their reliability and efficiency.

Hence, the aim of this paper is to perform a simulation of the belt speed adjustment for different excavator volume capacities. The research was performed on the belt conveyor J-III-4 for the transport of overburden used at the surface mine Drmno (Serbia). The wheel bucket excavator SRs $2000.32 / 5$ with a theoretical capacity of 6600 $\mathrm{m}^{3} / \mathrm{h}$ was used for excavation. The calculated belt speeds provide reliable and safe transition operations. The analysis was performed in the MATLAB software package, in which the existing comprehensive expressions were implemented. 


\section{THE BASIC PRINCIPLE OF THE CONVEYOR SPEED REGULATION}

The belt conveyor speed regulation can be defined as a method of adjusting the speed of the conveyor belt to match the cross section area of the material on the belt in order to reduce electricity consumption and wear of moving parts.

The flow of the transported material $Q\left(\mathrm{~m}^{3} / \mathrm{h}\right)$ is generally less than the nominal capacity of the conveyor, and is defined by the instantaneous cross section area of the material on the belt $A_{(t)}\left(\mathrm{m}^{2}\right)$ and the nominal belt speed $v_{n}(\mathrm{~m} / \mathrm{s})$ which is constant (Figure 1). Based on the law of conservation of the volume flow, the same volume of material can be transported by filling the belt to the nominal cross section area of the material $A_{n}\left(\mathrm{~m}^{2}\right)$ and changing the belt speed $v_{(t)}(\mathrm{m} / \mathrm{s})$, i.e.

$$
Q=\frac{1}{T_{t}} \int_{0}^{T_{t}} A_{(\ell)} \cdot v_{n} \cdot d t=\frac{1}{T_{t}} \int_{0}^{T_{t}} A_{n} \cdot v_{(t)} \cdot d t
$$

where:

$$
T_{t} \text { - observed time period. (s); }
$$

The required speed of the conveyor belt $v_{t}(\mathrm{~m} / \mathrm{s})$ in order to achieve the nominal cross section area of the material $A_{n}\left(m^{2}\right)$, is determined by rearranging the expression (1):

$$
v_{(t)}=\frac{A_{(t)}}{A_{n}} \cdot v_{n}
$$

where:

$v_{n}-$ nominal belt speed. $(\mathrm{m} / \mathrm{s})$

$A_{(t)}$ - current cross sectional area of the material on the belt, $\left(m^{2}\right)$;

$A_{n}$ - nominal cross section area of the material on the belt. $\left(m^{2}\right)$;

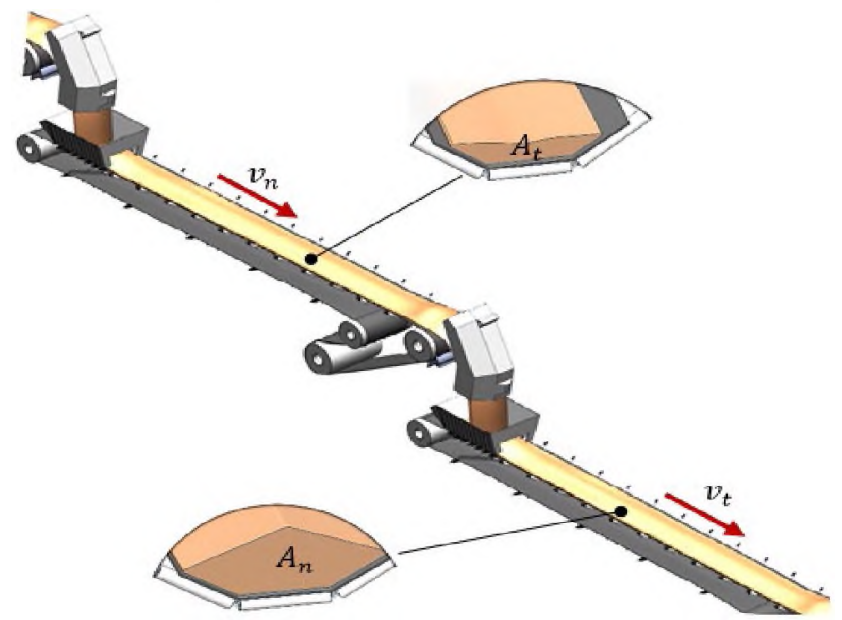

Figure 1. Basic principle of the speed control

\section{MATHEMATICAL MODEL}

One of the basic equations of the induction motor which describes the relationship between the moment of inertia $J\left(\mathrm{kgm}^{2}\right)$, the angular velocity $\omega(\mathrm{rad} / \mathrm{s})$ and the torque $T(\mathrm{Nm})$ is the following:

$$
\frac{d}{d t}(J \omega)=J \frac{d \omega}{d t}+\omega \frac{d J}{d t}=T-T_{\text {load }}
$$

In the above expression, it is assumed that both the frequency and the moment of inertia change. However, the expression (3) is usually formulated in such a way that the moment of inertia is considered constant.

$$
J \frac{d \omega}{d \ell}=T-T_{l o a d}
$$

where:

$T_{\text {load }}-$ motor torque. $(\mathrm{Nm})$ :

In belt conveyors. the load consists of the moment of friction, the moment of inertia and the load itself.

The motor torque can be assumed to consist of a dynamic component $T_{d y n}(N)$ and a load component $T_{\text {load }}(N)$.

$$
T=T_{d y n}+T_{\text {load }}
$$

If the velocity and moment of inertia are constant. the dynamic component $T_{d y n}(N)$ equals zero.

The dynamic torque component causes the acceleration/deceleration of the constant moment of inertia (the motor speed changes by $\Delta n\left(\mathrm{~min}^{-1}\right)$ in time $\Delta t(s)$. while the moment of inertia $J\left(\mathrm{kgm}^{2}\right)$ is constant), i.e.

$$
T_{d y n, n}=\jmath \cdot \frac{2 \pi}{60} \cdot \frac{\Delta \mathrm{n}}{\Delta \mathrm{t}}
$$

Also, the dynamic torque component causes a variable moment of inertia at a constant number of revolutions $\Delta n\left(\mathrm{~min}^{-1}\right)$ :

$$
\tau_{d y n, J}=n \cdot \frac{2 \pi}{60} \cdot \frac{\Delta \mathrm{J}}{\Delta \mathrm{t}}
$$

The acceleration time $t_{a}(s)$ with the nominal torque can be determined using the following expression:

where:

$$
\mathrm{t}_{a}=\frac{2 \pi}{60} \cdot \frac{J_{\text {tot }} \cdot \Delta n}{T_{n}-T_{\text {load }}}
$$

$J_{\text {tot }}-$ total moment of inertia of the system. $\left(\mathrm{kgm}^{2}\right)$;

$\Delta n-$ speed control range. $\left(\mathrm{min}^{-1}\right)$;

$T_{n}$ - nominal torque. $(\mathrm{Nm})$;

$T_{\text {load }}-$ load torque, $(\mathrm{Nm})$;

The total moment of inertia of the system includes the moment of inertia of the motor $J_{a m}\left(\mathrm{kgm}^{2}\right)$ (because the motor must overcome its own inertia), the moment of inertia of the gearbox $J_{g b}\left(\mathrm{kgm}^{2}\right)$, the moment of inertia of the pulley system $\sum J_{p}\left(\mathrm{kgm}^{2}\right)$ and the moment of inertia of the constant load $J_{\text {load }}\left(\mathrm{kgm}^{2}\right)$, where the moment of inertia of the pulley system $\sum J_{p}$ and the moment of inertia of the constant load $J_{\text {load }}$ are multiplied by the reciprocal value of the gear ratio of the gearbox $i$. i.e.

$$
J_{\text {tot }}=J_{a m}+J_{g b}+\left(\sum J_{p}+J_{l o a d}\right) \cdot \frac{1}{i^{2}}
$$

The inertia values of motors and gearboxes are usually determined by their manufacturers. However. the moments of inertia of the constant load $J_{\text {load }}$ and the pulley system $\sum J_{p}$ must be determined analytically. The constant load includes the mass of the material and the belt because the motor must generate the required torque in order to overcome the inertia of the belt:

where:

$$
J_{\text {load }}=L \cdot\left(2 q_{B}+q_{M}\right) \cdot R_{p}^{2}
$$

$L$ - total conveyor length. $(m)$

$q_{M}-$ mass per unit length of the load. $(\mathrm{kg} / \mathrm{m})$ :

$q_{B}-$ mass per unit length of the belt. $(\mathrm{kg} / \mathrm{m})$;

$R_{p}$ - radius of the pulley. $(m)$;

The moment of inertia of the pulley $J_{p}$ can be approximately determined using the expression:

$$
J_{p}=\frac{1}{2} \cdot \pi \cdot \rho_{p} \cdot B_{p} \cdot\left(R_{p . e x t}{ }^{4}-R_{p . i n t}{ }^{4}\right)
$$


where:

$\rho_{p}$ - density of the pulley material, $\left(\mathrm{kg} / \mathrm{m}^{3}\right)$;

$B_{p}$ - pulley width, $(m)$;

$R_{p . e x t}-$ outer radius of the coated pulley, $(m)$;

$R_{\text {p.int }}$ - inner radius of the coated pulley, $(m)$;

The value of the nominal torque is generally given in manufacturers catalogues but it can also be determined using the expression:

$$
T_{n}=9550 \cdot \frac{P_{a m}}{n_{a m}}
$$

where:

$P_{a m}$ - electric motor power, $(k W)$;

$n_{a m}$ - number of revolutions of the electric motor, $\left(\mathrm{min}^{-1}\right)$;

The load torque can be determined based on the expression:

where:

$$
T_{\text {load }}=\frac{F_{W} \cdot R_{p}}{u_{g b} \cdot \eta}
$$

$F_{W}$ - resistance at steady state operation, $(N)$;

$\eta$ - efficiency of the gearbox, coupling and electric motor;

The traction (driving) force $F_{W}$ should overcome all conveyor resistances to the motion. When starting the conveyor, there is resistance to horizontal movement of the loaded belt, resistance to rotation of all pulleys and rollers, resistance needed for lifting/lowering loads, resistance at loading points and, finally, special resistances that occur in special conditions. Based on this, the value of traction is determined by the expression:

$$
\begin{gathered}
F_{w}=L \cdot \mu \cdot \mathcal{C} \cdot g \cdot\left[q_{R, n}+q_{R, p}+\left(2 q_{B}+q_{M}\right) \cdot \cos \delta\right] \\
\pm H \cdot q_{M}+F_{S}
\end{gathered}
$$

where:

$\mu$ - hypothetical friction coefficient;

$C$ - correction coefficient whose value depends on the length of the conveyor;

$g$ - acceleration of gravity, $\left(\mathrm{m} / \mathrm{s}^{2}\right)$

$q_{R, n}$ - mass of troughing carrying pulleys per unit length, $(\mathrm{kg} / \mathrm{m})$;

$q_{R, p}$ - mass of return pulleys per unit length, $(\mathrm{kg} / \mathrm{m})$;

$\delta$ - inclination angle of the conveyor relative to the horizontal, $\left({ }^{\circ}\right)$;

$H$ - height difference between the infeed and outfeed ends of the whole conveyor, $(m)$;

$F_{S}$ - additional resistances to motion that occur in special conditions, $(N)$.

The speed change profile is also very important for the belt acceleration/deceleration because the occurrence of mechanical jerks and shocks depends on it. As a result, several speed change profiles have been designed in recent decades [14]. However, since this paper mainly deals with the method used to decide on the change of speed and acceleration/deceleration time, the details of the acceleration profiles and their effects on the dynamic behaviour of the belt will not be further studied. The paper uses Harrison's [17] sinusoidal acceleration profile whose mathematical expressions for calculating velocity and acceleration are as follows:

$$
a(t)=\frac{\pi}{2} \cdot \frac{\Delta v}{t_{a}} \cdot \sin \frac{\pi t}{t_{a}}
$$

$$
v(t)=v_{0}+\frac{\Delta v}{2} \cdot\left(1-\cos \frac{\pi t}{t_{a}}\right)
$$

where:

$\Delta v$ - speed regulation range, $(\mathrm{m} / \mathrm{s})$;

$v_{0}$ - initial speed before the transient operation, $(\mathrm{m} / \mathrm{s})$;

$t$ - instantaneous time, (s);

The motor thermal operability, defined as the maximum long-term overheating, must also be taken into account when changing the belt speed.

Electrical and mechanical equipment must be able to withstand short-term overloads which occur at belt speeds higher than nominal.

According to the recommendations of $A B B[18]$ as a leading manufacturer in the field of energy and automation, asynchronous motors may be overloaded for a short period of time without overheating. The time needed for the motor temperature to rise depends on the size of the motor and it usually varies from 15 minutes for small motors up to several hours for large motors. However, motor overload periods are usually much shorter in belt conveyors at surface mines.

\section{MODEL TESTING AND SIMULATION RESULTS}

\begin{tabular}{|c|c|c|}
\hline \multirow{3}{*}{ Basic data } & Conveyor length, $(m)$ & 640 \\
\hline & Conveyor lifting height, $(\mathrm{m})$ & 21 \\
\hline & Nominal belt speed, $(\mathrm{m} / \mathrm{s})$ & 4,65 \\
\hline \multirow{2}{*}{ Material } & Volumetric capacity, $\left(\mathrm{m}^{3} / \mathrm{h}\right)$ & 6600 \\
\hline & Density of the bulk material, $\left(t / \mathrm{m}^{3}\right)$ & 1,6 \\
\hline \multirow{3}{*}{ Belt } & Belt type & ST 3150 \\
\hline & Belt width, $(\mathrm{mm})$ & 2000 \\
\hline & Belt thickness, $(\mathrm{mm})$ & 31,5 \\
\hline \multirow{6}{*}{ Idlers } & Carrying idlers, $(\mathrm{mm})$ & $\varnothing 194 \times 750$ \\
\hline & $\begin{array}{l}\text { Mass of the troughing carrying idler } \\
\text { sets, }(\mathrm{kg})\end{array}$ & 152 \\
\hline & \begin{tabular}{|l|} 
Spacing distance between two \\
troughing carrying idler sets, $(\mathrm{mm})$
\end{tabular} & 1800 \\
\hline & Return idlers, $(\mathrm{mm})$ & $0219 \times 1150$ \\
\hline & Mass of the return idler set, $(\mathrm{kg})$ & 142 \\
\hline & $\begin{array}{l}\text { Spacing distance between two return } \\
\text { idler sets, }(\mathrm{mm})\end{array}$ & 3600 \\
\hline \multirow{3}{*}{ Pulleys } & Drive pulley diameter, $(\mathrm{mm})$ & 01500 \\
\hline & Tension pulley diameter, $(\mathrm{mm})$ & 01250 \\
\hline & Return pulley diameter, $(\mathrm{mm})$ & $\varnothing 1250$ \\
\hline \multirow{3}{*}{ Gearbox } & Gearbox type & $\begin{array}{l}\text { Flender } \\
\text { B3FE19 } \\
\end{array}$ \\
\hline & Gear ratio & 17,267 \\
\hline & Gearbox moment of inertia, $\left(\mathrm{kgm}^{2}\right)$ & $6,84 \cdot u_{g b}^{2}$ \\
\hline \multirow{5}{*}{$\begin{array}{l}\text { Electric } \\
\text { motor }\end{array}$} & Electric motor type & \begin{tabular}{|c|} 
RZKIT 560 \\
L-6 B3 \\
\end{tabular} \\
\hline & Power, $(k W)$ & 1000 \\
\hline & Number of installed motors & 3 \\
\hline & $\begin{array}{l}\text { Number of revolutions of the electric } \\
\text { motor, }\left(\mathrm{min}^{-1}\right)\end{array}$ & 980 \\
\hline & $\begin{array}{l}\text { Moment of inertia of the electric } \\
\text { motor, }\left(\mathrm{kgm}^{2}\right)\end{array}$ & 109 \\
\hline
\end{tabular}

The research was performed on the belt conveyor J-III-4 used for the transport of overburden at the surface mine Drmno (Serbia). The basic characteristics of the conveyor are given in Table 1 and Figures 2 and 3.

Table 1: Basic characteristics of the tested belt conveyor 


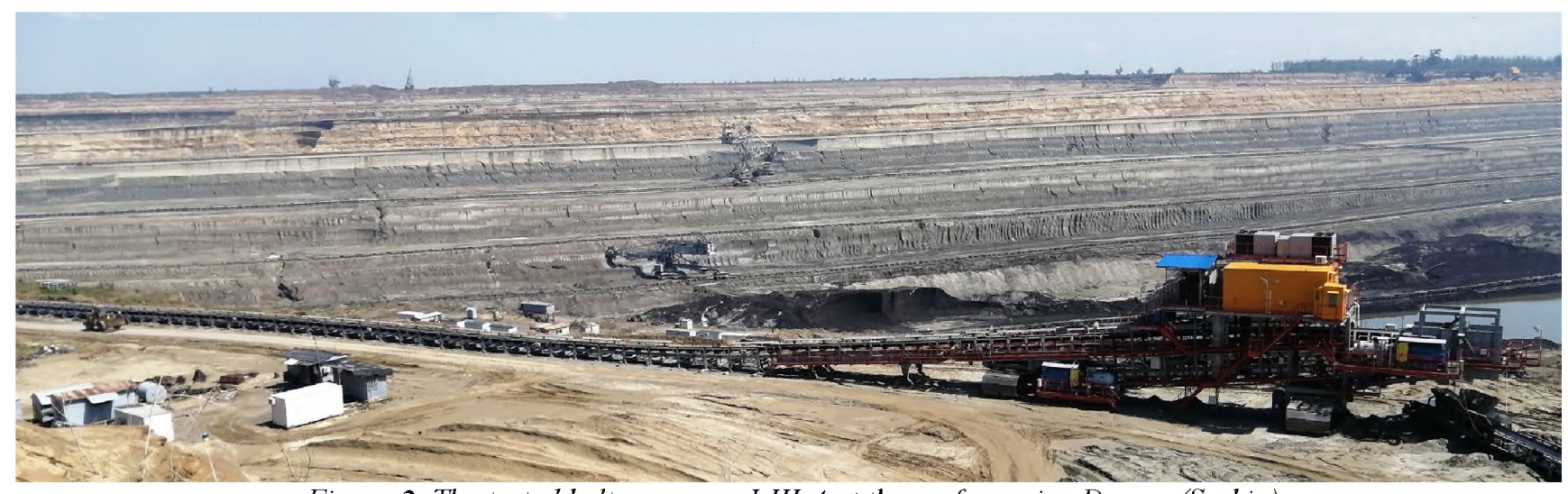

Figure 2. The tested belt conveyor J-III-t at the surface mine Drmno (Serbia)

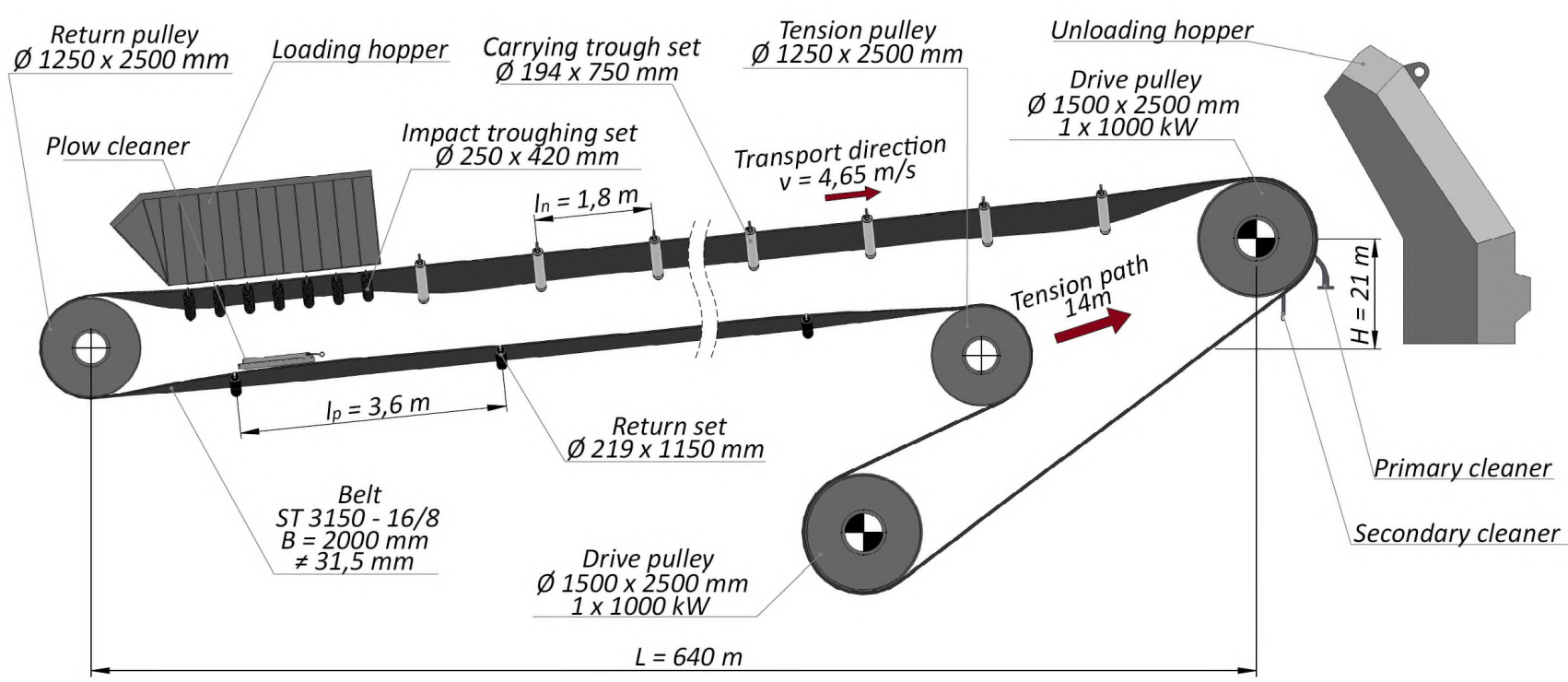

Iigure 3. Schematic drawing of the tested belt conveyor and its main components

Takraf's bucket wheel excavator SRs $2000.32 / 5$ with a theoretical capacity of $6600 \mathrm{~m}^{3} / \mathrm{h}$ was used for excavation. During 2020, the excavator worked $330 \mathrm{~h}$ per month on average with a capacity of $2730 \mathrm{~m}^{3} / \mathrm{h}$, which is $41,36 \%$ of the theoretical capacity of the belt conveyor.

The instantaneous amount of material $\left(\mathrm{m}^{3} / \mathrm{h}\right)$ transported is almost never constant because of the digging technology. Figure 4 shows a typical diagram of the instantaneous amount of material recorded during 6 minutes of operation. The minimum peaks are the consequence of the excavator exiting and re-entering the cut when it grips very little material from the massif or not at all.

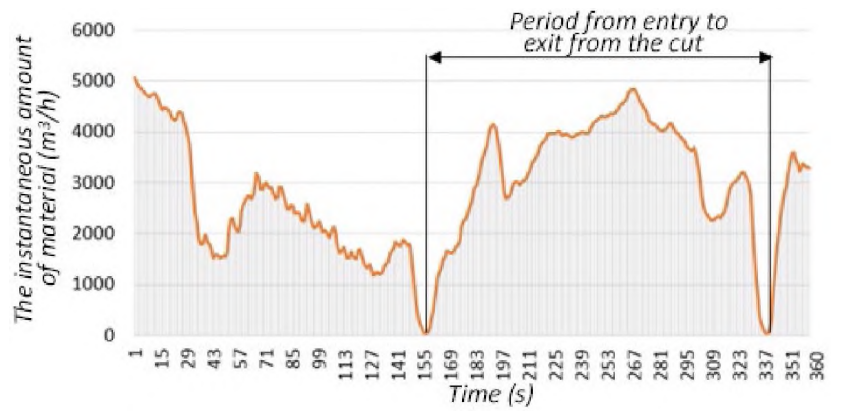

ligure 4. Instantaneous amount of material recorded on the wheel bucket excavator SRs 2000.32 5

The value of the instantaneous capacity varies in a wide range from 0 to $77 \%$ very abruptly. The speed of the belt should be increased or decreased in the same manner as the instantaneous capacity changes. These dynamic processes are quite unfavourable for the belt conveyor elements, especially for the electric motor and the belt.

Ristic [8] suggests that the belt speed should be adjusted only if the needed speed is at least $10 \%$ higher than the current belt speed, while He, Pang and Lodewijks [15] suggest that it should be at least $15 \%$ higher, i.e.

$$
\frac{v_{n}-v_{t}(t)}{v_{n}} \cdot 100 \% \geq 10 \div 15 \%
$$

In order to obtain the most realistic picture, the belt speed was simulated for the instantaneous value of the amount of material shown in Figure 4. The belt speed was changed in five intervals. The simulation results are shown in Figure 5. The intervals are defined in the range of $15 \%$, except the first interval which covers all the speeds less than $40 \%$ :

$$
\begin{array}{ll}
\text { 1. } & <40 \%(1.86 \mathrm{~m} / \mathrm{s}) \\
\text { 2. } & 40-55 \%(2.55 \mathrm{~m} / \mathrm{s}) \\
\text { 3. } & 55-70 \%(3.25 \mathrm{~m} / \mathrm{s}) \\
\text { 4. } 70-85 \%(3.95 \mathrm{~m} / \mathrm{s}) \\
\text { 5. } & 85-100 \%(4.65 \mathrm{~m} / \mathrm{s})
\end{array}
$$

As it can be seen in Figure 5, the conveyor operated at speeds less than nominal all the time: $65 \%$ of the time $(234 \mathrm{~s})$ at a speed of $1,86 \mathrm{~ms}, 32,22 \%(116 \mathrm{~s})$ at a speed of $2,55 \mathrm{~m} / \mathrm{s}$ and $2,78 \%(10 \mathrm{~s})$ at a speed of $3,25 \mathrm{~m} / \mathrm{s}$.

Figure 6 shows the details of the speed profile changes at characteristic points. The profile is sinusoidal in order to avoid occurrence of mechanical jerks and shocks. 


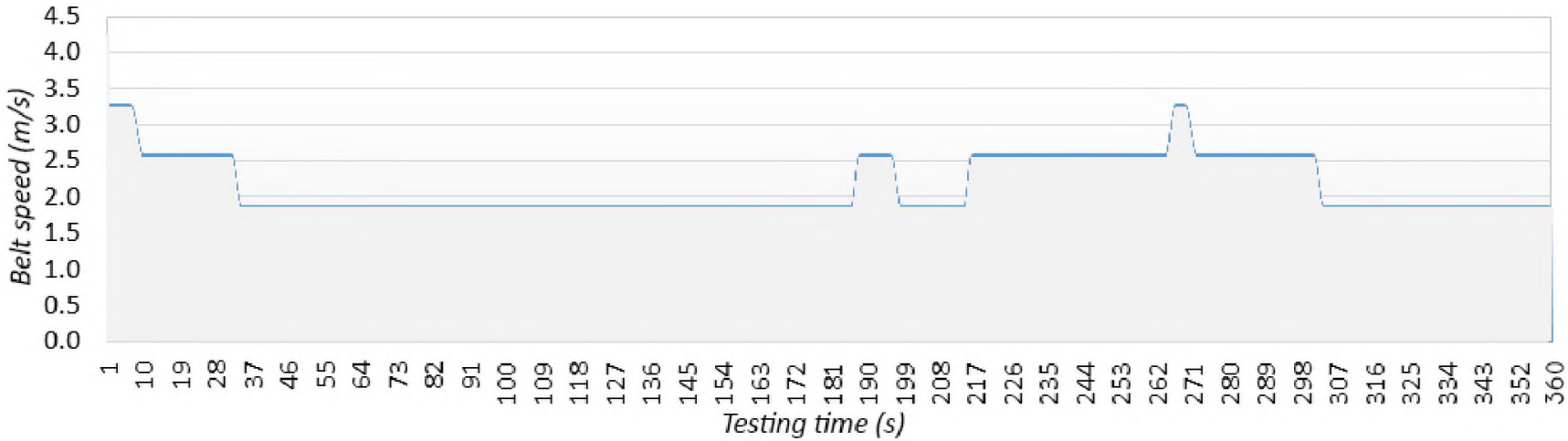

Figure 5. Instantaneous value of the speed as a function of the instantaneous amount of material on the belt

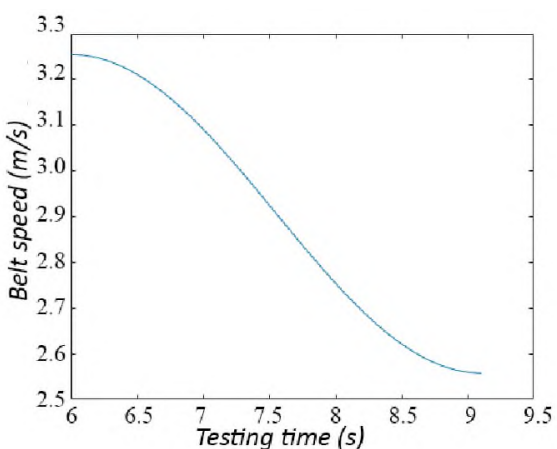

a)

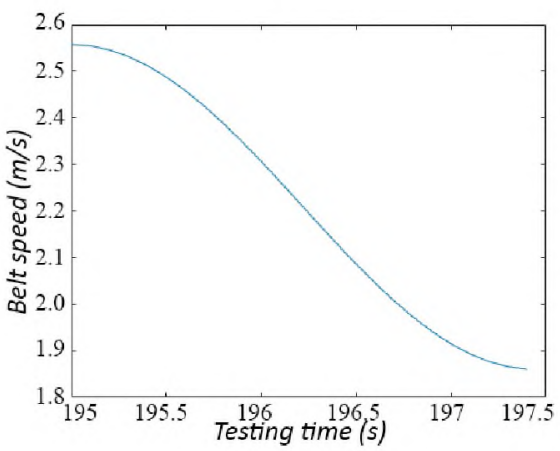

d)

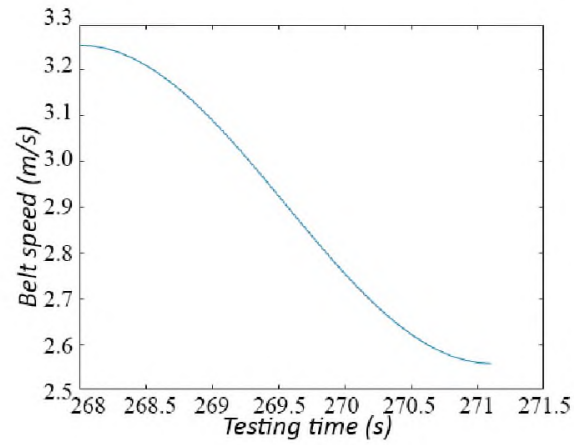

g)

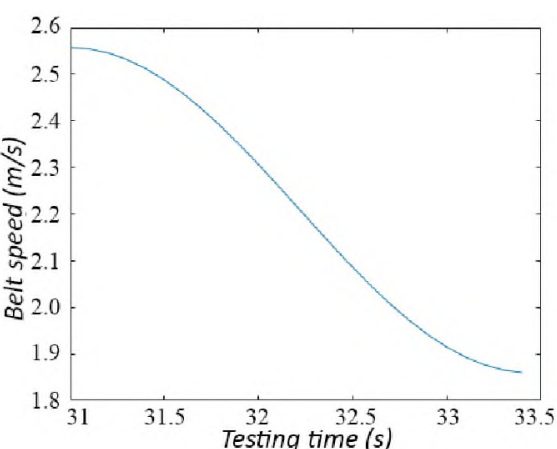

b)

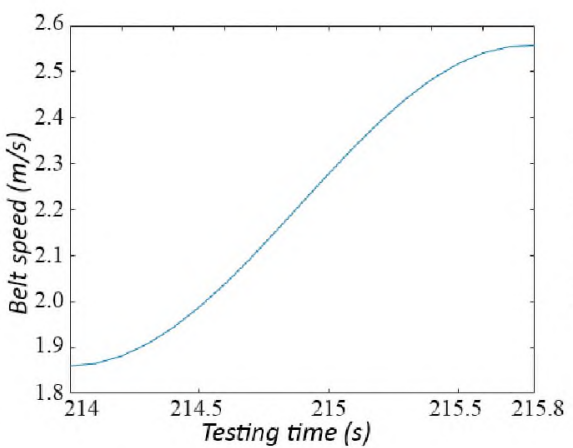

e)

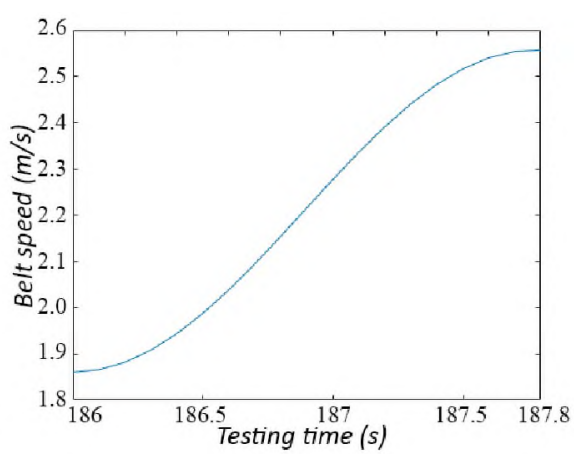

c)

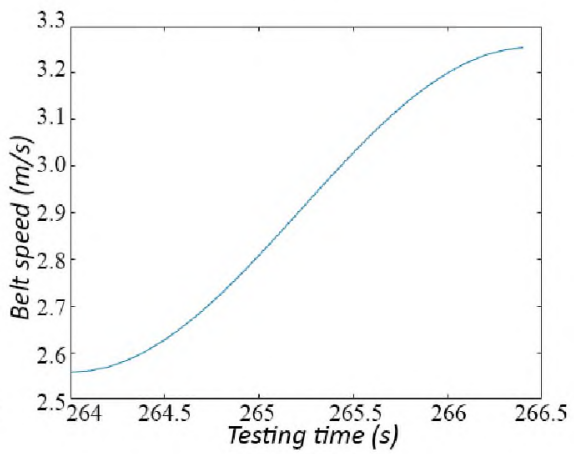

f)

Figure 6. Details of acceleration and deceleration

It takes $3.1 \mathrm{~s}$ for deceleration from $3.25 \mathrm{~m} / \mathrm{s}$ to 2.55 $\mathrm{m} / \mathrm{s}$ (Figure 6.a). which occurs after 6 seconds of testing. The time needed for further deceleration from $2.55 \mathrm{~m} / \mathrm{s}$ to $1.86 \mathrm{~m} / \mathrm{s}$ (Figure 6.b) that occurs in the $31^{\text {st }}$ second of testing is not the same - it is $2.4 \mathrm{~s}$. This difference in the time required for deceleration is the result of different masses $q_{M}(\mathrm{~kg})$ and inertia $J_{\text {load }}\left(\mathrm{kgm}^{2}\right)$ of the transported material. In the $6^{\text {th }}$ second of testing. the instantaneous amount of the transported material is $4783 \mathrm{~m}^{3} / \mathrm{h}$ while in the $31^{\text {st }}$ second. it is $3473 \mathrm{~m}^{3} / \mathrm{h}$.
The identical response of the system occurs when the speed increases. It takes $1.8 s$ for acceleration from 1.86 $\mathrm{m} / \mathrm{s}$ to $2.55 \mathrm{~m} / \mathrm{s}$ (Figure 6.c) and it occurs in the $186^{\text {th }}$ second of testing. The time for further acceleration from $2.55 \mathrm{~m} / \mathrm{s}$ to $3.25 \mathrm{~m} / \mathrm{s}$ (Figure 6.e) that occurs in the $264^{\text {th }}$ second is not the same - it is $2.4 \mathrm{~s}$. In the $186^{\text {th }}$ second of testing. the instantaneous amount of the transported material is $3430 \mathrm{~m}^{3} / \mathrm{h}$. while in the $264^{\text {th }}$ second, it is 4763 $m^{3} / h$. 


\section{CONCLUSION}

This paper presents a procedure for adjusting the belt conveyor speed to match the cross section area of the material on the belt, as well as a detailed procedure for determining the time needed to accelerate/decelerate the belt conveyor.

The research was performed on an actual $640 \mathrm{~m}$ long belt conveyor used for transport of overburden at the surface mine Drmno (Serbia).

Analysis of the results shows that the speed adjustment is completely justified because throughout the testing the conveyor had to operate at speeds lower than nominal $(4,65 \mathrm{~m} / \mathrm{s})$ in order for the belt to be filled.

During $360 \mathrm{~s}$ of testing, the conveyor operated at a speed of $1,86 \mathrm{~m} / \mathrm{s}$ for $65 \%$ of the time $(234 \mathrm{~s})$, at a speed of $2.55 \mathrm{~m} / \mathrm{s}$ for $32.22 \%$ of the time $(116 \mathrm{~s})$ and at a speed of $3,25 \mathrm{~m} / \mathrm{s}$ for $2,78 \%$ of the time $(10 \mathrm{~s})$. In this way, a significant reduction in electricity consumption is achieved, which has an impact on the overall energy efficiency.

Furthermore, different time periods are needed for the speed change to occur (acceleration/deceleration). It takes $3,1 \mathrm{~s}$ to slow down from $3,25 \mathrm{~m} / \mathrm{s}$ to $2,55 \mathrm{~m} / \mathrm{s}$. The time for further deceleration from $2,55 \mathrm{~m} / \mathrm{s}$ to $1,86 \mathrm{~m} / \mathrm{s}$ is $2,4 \mathrm{~s}$. The identical response of the system occurs when the speed is increased. It takes $1,8 \mathrm{~s}$ for acceleration from 1,86 $\mathrm{m} / \mathrm{s}$ to $2,55 \mathrm{~m} / \mathrm{s}$. For further acceleration from $2,55 \mathrm{~m} / \mathrm{s}$ to $3,25 \mathrm{~m} / \mathrm{s}$, it takes $2,4 \mathrm{~s}$. These different time periods needed for acceleration/deceleration are the direct result of different instantaneous weights and inertia of the material being transported and they were taken into account when defining the mathematical model.

The thermal operability of the motor, defined as the maximum long-term overload, must also be taken into account when changing the belt speed. Electrical and mechanical equipment must be able to withstand short-term overloads that occur at belt speeds higher than nominal. During our testing, the belt conveyor did not have to operate at speeds higher than nominal so there was no risk of motor overheating.

Our further research will be devoted to the possibility and justification of speed regulation for a multiple belt conveyor system.

\section{REFERENCES}

[1] DIN 22101:2011. Continuous conveyors - Belt conveyors for loose bulk materials - Basis for calculation and dimensioning.

[2] B. Kolonja, B. Jeftenić, D. Ignjatović, "The application of frequency converters for the regulation of belt conveyor drives in surface mining", The International Journal of Transport \& Logistics, Vol. (5), pp.11-27, (2003)

[3] M. Simonović, " Machines for digging and transport of excavated material and plants for deep drilling on surface excavations", Faculty of Mining and Geology, Belgrade, (1982)

[4] V. Pavlović, "Surface Excavation Technology", Faculty of Mining and Geology, Belgrade, (1989)

[5] J. Hiltermann, G. Lodewijks, D. L. Schott, J. C. Rijsenbrij, J. A. J. M. Dekkers, Y. Pang, "A Methodology to Predict Power Savings of Troughed
Belt Conveyors by Speed Control", Particulate Science and Technology, Vol. 29 (1), pp. 14-27, (2011).

[6] S. Zhang, X. Xia, "A new energy calculation model of belt conveyor", Institute of Electrical and Electronics Engineers, pp. 1-6, (2009)

[7] L. Ristić, M. Bebić, D. Jevtić, I. Mihailović, S. Štatkić, N. Rašić, B. Jeftenić, "Fuzzy speed control of belt conveyor system to improve energy efficiency", 15th International Power Electronics and Motion Control Conference, pp. 1-7, (2012)

[8] L. Ristić, "Development of the Algorithm for Energy Efficiency Improvement of Belt Conveyor System on Open Pit Mines", Doctoral Dissertation, Faculty of Electrical Engineering, University of Belgrade, Belgrade, (2012)

[9] M. Bebić, L. Ristić, "Speed Controlled Belt Conveyors: Drives and Mechanical Considerations", Advances in Electrical and Computer Engineering, Vol. 18 (1), pp. 51-60, (2018)

[10] J. Ji, C. Miao, X. Li, "Research on the energy-saving control strategy of a belt conveyor with variable belt speed based on the material flow rate", PLoS ONE, Vol. 15 (1), pp. 1-14, (2020)

[11] B. Karolewski, P. Ligocki, "Modelling of long belt conveyors", Eksploatacja i Niezawodnosc Maintenance and Reliability, Vol. 16 (2), pp. 179-187, (2014)

[12] S. Gramblička, R. Kohar, M. Stopka, "Dynamic analysis of mechanical conveyor drive system", Procedia Engineering, Vol. 192, pp. 259-264, (2017)

[13] J. Li, X. Pang, "Belt Conveyor Dynamic Characteristics and Influential Factors", Shock and Vibration, pp. 1-13, (2018)

[14] D. He, Y. Pang, G. Lodewijsk, "Determination of Acceleration for Belt Conveyor Speed Control in Transient Operation", IACSIT International Journal of Engineering and Technology, Vol. 8 (3), pp. 206-211, (2016)

[15] D. He, Y. Pang, G. Lodewijsk, "Belt Conveyor Dynamics in Transient Operation for Speed Control", International Journal of Civil, Environmental, Structural, Construction and Architectural Engineering, Vol. 10 (7), pp. 836-841, (2016)

[16] D. He, Y. Pang, G. Lodewijks, X. Liu, "Healthy speed control of belt conveyors on conveying bulk materials", Powder Technology, Vol. 327, pp. 408-419, (2018)

[17] Harrison, "Criteria for minimising transient stress in conveyor belts", Mechanical Engineering Transactions, Vol. 8 (3), pp. 129-134, (1983)

[18] ABB, "Dimensioning of a drive system", Technical Guide, Vol. (7), (2019) 


\section{Kontrola brzine višepogonskih trakastih transportera velikih snaga}

Milan Vasić1 ${ }^{*}$, Nenad Miloradović ${ }^{1}$, Mirko Blagojević ${ }^{1}$, Univerzitet u Kragujevcu, Fakultet inženjerskih nauka, Kragujevac (Srbija)

Trakasti transporteri imaju veoma važnu ulogu u kontinuiranom transportu rasutog i komadnog materijala, posebno u rudarskoj industriji. Medutim, upotreba trakastih transportera, rezultuje veliku potrošnju električne energije. Odgovarajuće smanjenje potrošnje električne energije može se ostvariti podešavanjem brzine transportera tako da odgovara protoku materijala. Medutim, neodgovarajuće i učestale promene brzine mogu prouzrokovati ozbiljna oštećenja elemenata transportera. $U$ ovom radu predstavljen je postupak koji odlučuje o promeni brzine u zavisnosti od profila materijala na traci, kao i detaljan postupak za odredivanje potrebnog vremena za ubrzanje/usporenje. Istraživanje je izvršeno za konkretan trakasti transporter dužine 640 koji se upotrebljava za transport otkrivke na površinskom kopu Drmno (Srbija). Rezultati simulacije pokazuju da je promena brzine $u$ potpunosti opravdana jer transporter sve vreme testiranja radi sa brzinom manjom od nominalne.

Ključne reči: Trakasti transporteri, Regulacija brzine, Dinamičko ponašanje 